\title{
Families in the Context of Macroeconomic Crises: A Systematic Review
}

\author{
Gabriela Fonseca and Diana Cunha \\ University of Coimbra
}

\author{
Carla Crespo \\ University of Lisbon
}

\author{
Ana Paula Relvas \\ University of Coimbra
}

\begin{abstract}
The present study is a systematic review of empirical literature from the last 35 years on families' responses to economic distress in the context of macroeconomic crises. Thirty-nine studies published between 1983 and 2015 in 12 countries were identified, resulting in 3 main findings. First, economic distress was associated with negative changes in family dynamics, specifically couple relationships and parenting. Second, protective factors were found to buffer the adverse effects of economic distress on family and individual outcomes. Third, the results suggest that individual responses to macroeconomic crises may be moderated by sex. Implications for future research encompass using validated assessment instruments, including participants beyond 2-parent families with adolescent children and conducting both longitudinal and qualitative studies that focus on the processes and meanings of adaptation within this risk context. Conclusions highlighted the need to assist families dealing with macroeconomic crises' demands, encouraging the development and validation of macrosystemic intervention programs.
\end{abstract}

Keywords: macroeconomic crises, economic distress, family dynamics, couples' relationships, parenting

Macroeconomic crises occur cyclically and entail devastating social consequences for individuals, families, and communities. Because of the 2008 global recession, a number of countries worldwide were forced into a context of social and economic crisis and have experienced increased unemployment, reduced wages and remittances, declining living standards, large inequalities in the distribution of wealth, and political instability (Aytaç \& Rankin, 2009; Brooks-Gunn, Schneider, \& Waldfogel, 2013; De Vogli, 2014).

Historically, research addressing families' responses to drastic socioeconomic changes was first developed when the U.S. endured severe economic circumstances during the Great Depression of the 1930s (Hraba, Lorenz, \& Pechacova, 2000). Overall, these findings suggested linkages between family economic distress and marital conflict that often culminated in relationship dissolution and family conflict, as well as child abuse and neglect (Conger et al., 1990; Leininger \& Kalil, 2014). This topic was also extensively studied in the 1980s because of the U.S. agricultural crisis, which resulted in significant research progress. A particularly important step was the development of the family stress model (FSM; Conger \& Elder, 1994), a framework that describes how families might be negatively affected by economic hardship.

Gabriela Fonseca and Diana Cunha, Faculty of Psychology and Educational Sciences, University of Coimbra; Carla Crespo, Faculty of Psychology, University of Lisbon; Ana Paula Relvas, Faculty of Psychology and Educational Sciences, University of Coimbra.

Correspondence concerning this article should be addressed to Gabriela Fonseca, Faculty of Psychology and Educational Sciences, University of Coimbra, Rua do Colégio Novo, 3001-802 Coimbra, Portugal. E-mail: gabrielafonseca@fpce.uc.pt
Currently, in the aftermath of an economic downturn described as one of the worst crises in contemporary history, research on families' experience of macroeconomic crises has gained significant momentum. Compared to individual and family level crises, it is possible that macroeconomic negative events entail a differential impact, as individuals and families might fear and anticipate the effects of the crisis with greater intensity and perceive its costs as being especially long lasting (e.g., lower expectations in finding a new job after losing the previous one). Nonetheless, the topic of families' enduring times of macroeconomic crisis still has received limited research attention.

Families, as microsystems surrounded by a wider context, are necessarily dependent on sociocultural and economic conditions (Bronfenbrenner, 1979). Feared, foreseen or observed negative events associated with macroeconomic trends (e.g., unemployment) may challenge the families' confidence regarding one of their chief functions, which is to provide basic means of subsistence for family members (Voydanoff, 1990).

According to the family adjustment and adaptation response model (FAAR model; McCubbin \& Patterson, 1983), when exposed to demands (e.g., stress events, tensions, daily concerns) that exceed by nature and/or number the families' capabilities (in terms of resources, coping), families undergo a state of disequilibrium or crisis. Strains associated with the context of the macroeconomic crisis might constitute such overwhelming demands for some families that significant efforts are required to restore balance to a family's functioning. In fact, two approaches have recognized the significant demand of economic difficulties on families. Voydanoff (1990) coined the concept of economic distress to refer to the aspects of economic life that become potential stressors for individuals and families. As a multidimensional construct, economic distress involves dimensions related to objective economic factors (e.g., changes in income over time) and dimensions based 
on subjective economic indicators, such as the concept of economic strain (the individual evaluation of one's current financial situation; Voydanoff, 1990). Later, within the context of FSM, Conger and colleagues proposed the concepts of economic hardship to refer to objective indicators of adverse economic conditions (e.g., income loss) and economic pressure to address the day-today frustrations (e.g., inability to pay bills by the end of the month) that give psychological meaning to hardship experiences (Conger \& Conger, 2002). The FSM established an indirect influence of economic hardship on child well-being through increased economic pressure, parents' psychological distress and disruptions in marital relationships, as well as parenting practices (Conger \& Conger, 2002; Conger \& Elder, 1994).

In addition to recognizing the possible adverse effects of economic crises on family life, the literature has also suggested that families' responses to economic distress vary. Within this line of research, two important reviews have focused on the factors and processes that U.S. families used to deal with economic difficulties during the 1980s (Conger \& Conger, 2002; Voydanoff, 1990). In the work of Voydanoff (1990), personal coping resources such as stable personality characteristics and family coping resources based on family adaptability and cohesion, effective problemsolving, and strong marital bonds before the economic distress were identified as buffers against the impact of economic distress. The work from Conger and Conger (2002) demonstrated that resilience in economic adversity was promoted by marital support, affecting problem-solving skills and mastery among parents of adolescent children, and by support from parents, siblings, and other adults outside of the family in the case of adolescents.

These reviews were ascribed to the 1980s recessionary periods in the US; since then, a number of studies in different national contexts have addressed families' responses to macroeconomic crises. The purpose of the present review is to provide a comprehensive, up-to-date picture of the literature on families in the context of macroeconomic crises by reviewing empirical research from the last 35 years in this domain. More specifically, guided by a general family stress approach (i.e., the FAAR model), this review is aimed at identifying families' functioning while experiencing a possible demand-capability imbalance prompted by macroeconomic crises, and identifying the processes through which families manage to adjust and adapt to this risk context. This theoretical framework was adopted to favor a broader approach to the processes that families, as a whole, undergo during economically challenging times.

\section{Method}

\section{Data Sources and Literature Search}

A computerized literature search was conducted in four databases that encompassed different fields of research: Web of Science (core collection), PsycINFO, SocINDEX and ERIC. The research strategy focused on economic conditions and family level dimensions through a combination of the following terms: ["economic downturn" OR "economic recession" OR "economic crisis" OR "financial crisis" OR "economic decline" OR "economic hardship" OR "economic pressure" OR "economic strain" OR "economic uncertainty"] AND [famil" OR marital OR couple* OR parent* ${ }^{*}$. Because studies that focused on families that lived during economic hard times began after Elder and colleagues' work on the U.S.'s Great Depression with their first published empirical articles in the 1980s, we opted to focus on studies that were written in English published between January 1980 and June 2015 inclusively. In addition to database searches, a manual examination of selected articles' reference lists was performed to identify other relevant studies for the review.

\section{Selection Procedures}

Following the database searches, duplicated records were identified and removed either electronically, through EndNote (Thomson Reuters, U.S.) or manually by examining the selected articles. A total of 2,458 nonduplicated records were identified, of which 2,421 were excluded. The inclusion criteria for the selected studies were as follows: (a) empirical studies that used quantitative or qualitative methods, or both; (b) studies whose participants had been exposed to a macroeconomic crisis; (c) studies with a focus on family level factors such as family, couple, and/or parenting dynamics as study variables (quantitative studies) or category/ theme (qualitative studies). The exclusion criteria were as follows: (a) studies whose authors did not clearly specify if the participants had been dealing with the demands of a macroeconomic crisis, (b) studies that assessed family-related variables that did not concern a relational perspective (e.g., families' savings, marriage/divorce rates), (c) studies not written in English. Initially, the first author screened the titles and abstracts of the selected records, identifying 185 potentially relevant studies for the review. In the following phase, the first two authors independently examined the full texts of those studies according to the defined inclusion and exclusion criteria. In the few cases for which the authors disagreed regarding an article's inclusion, consensus was reached after discussion. As recommend by PRISMA, the interrater agreement was calculated. Cohen's kappa coefficient indicated strong agreement $(\kappa=.818$; McHugh, 2012). Concerning the manual searches, 2 new studies were added to the initial 37 (Conger, Conger, et al., 1993; Ponnet, Wouters, Goedemé, \& Mortelmans, 2014). Figure 1 depicts the flowchart of the study selection process.

\section{Results}

\section{Studies' Characteristics}

Studies' context and design. Taken together, the electronic and manual searches yielded a total of 39 unique records. The studies were conducted between 1983 and 2015 in widely known contexts of both national and international downturns. The majority of the studies were carried out in the U.S. $(n=22)$ during the Great Depression in the 1930s $(n=2)$, the agricultural crisis in the 1980s $(n=13)$. and the most recent economic recession between 2007 and $2009(n=7)$. In Europe, 5 studies were carried out in Finland, and 7 were conducted, 1 each, in Germany, the Czech Republic, Albania, Romania, Bulgaria, Turkey, and Belgium. Beyond the U.S. and Europe, studies were conducted in Argentina $(n=3)$, South Korea $(n=1)$ and Singapore $(n=1)$. The majority of studies were cross-sectional $(n=28)$, with 10 employing a longitudinal design. One particular study (Solantaus, Leinonen, \& Punamäki, 2004) encompassed both cross-sectional and longitudinal components. All of the studies adopted a quantitative method- 


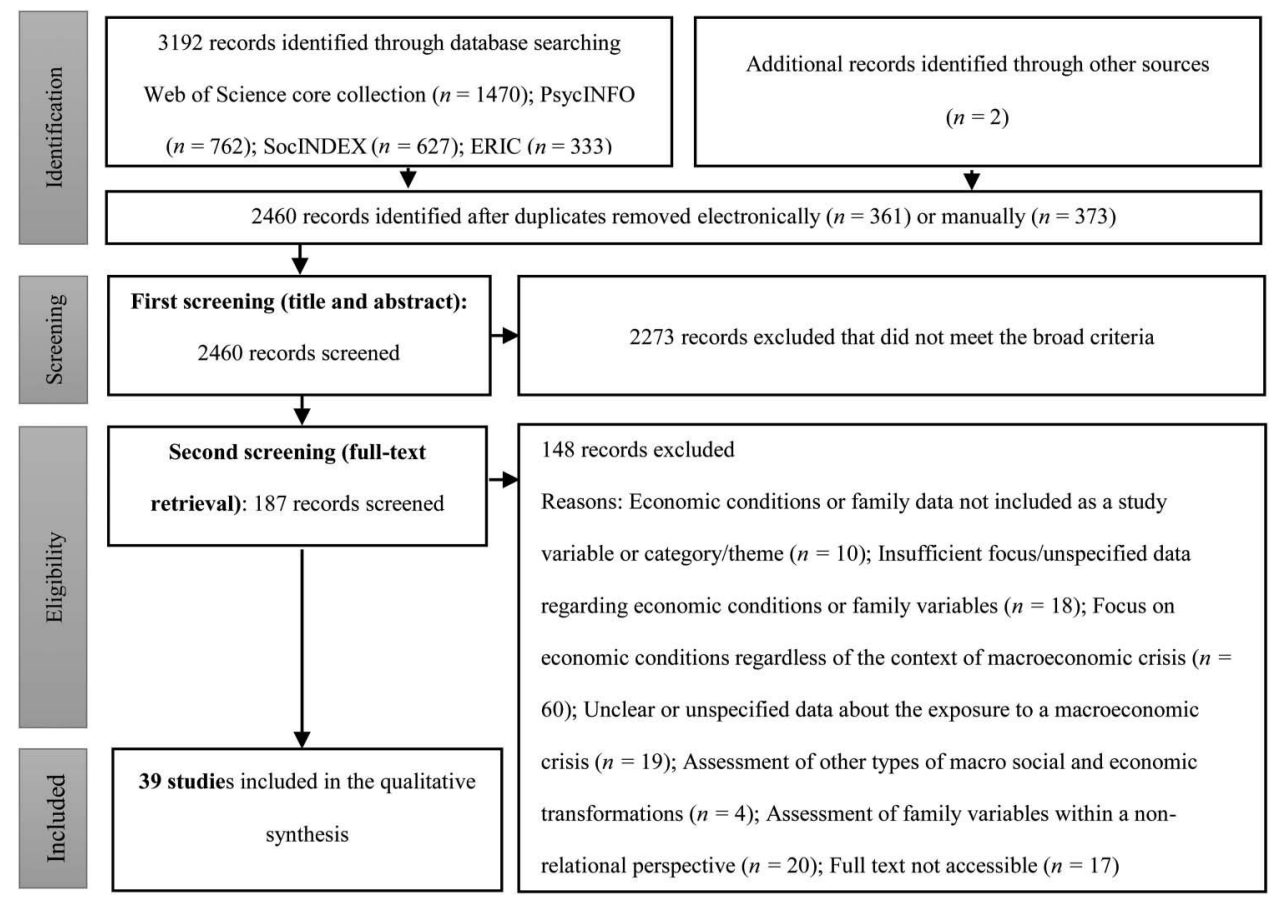

Figure 1. Flow chart of the study-selection process.

ology, with 1 mixed-method study that also comprised interviews with family members, whose quotations were used to illustrate the quantitative findings (Botcheva \& Feldman, 2004). In addition, it is important to note that 10 studies from Conger and Elder's team included qualitative data (e.g., observations of different family interactions) that were further codified in a quantitative way (e.g., Conger, Ge, Elder, Lorenz, \& Simons, 1994). Table 1 provides information regarding the context of the macroeconomic crisis, the study design, and the main variables assessed for each study.

Studies' participants. In the studies that focused on couple relationships, the samples were mainly composed of married or cohabiting couples $(n=12)$. Four studies included married individuals, of which 1 included only women as the participants (Robila \& Krishnakumar, 2005) and 2 included mainly women (Aytaç \& Rankin, 2009; Johnson \& Booth, 1990). Five studies included couples with adolescent children, and the remaining studies did not report data on children. Finally, 3 studies comprised a clinical sample; specifically, the participants were attending individual, marital, or family psychotherapy (Falconier, 2010; Falconier \& Epstein, 2010, 2011). Among the studies that focused on parenting dimensions, whether exclusively or along with an assessment of couple-related variables, the majority included adolescents and both of their parents as participants $(n=14)$.

One study included adolescents and their mothers (89\%), fathers $(6 \%)$, or even grandmothers $(5 \%)$ as primary caregivers (Elder, Eccles, Ardelt, \& Lord, 1995). Another study included reports from adolescents and their parents between 1989 and 1991 and reports from those adolescents when they became adults years later with their own young children (Conger, Schofield, Conger, \& Neppl, 2010). Two studies focused on families with young children and included the children and/or their mothers (Brooks-Gunn et al., 2013) or both their parents (Puff \& Renk, 2014). One last study highlighted the dynamics between emerging adults and their parents (Stein et al., 2011). Finally, the studies that included family global measures involved young children and/or adolescents and their parents $(n=2)$ or individuals from different families $(n=2)$.

Participants' socioeconomic status. Within the studies that provided information about the participants' socioeconomic status, the majority included middle-class $(n=15)$ and low- to middleclass families $(n=4)$. Only 2 studies (Elder et al., 1995; Helms et al., 2014) assessed economically disadvantaged families.

\section{Assessed variables and instruments.}

Economic conditions. As a central construct of interest, economic conditions were assessed in all of the selected studies. The majority of studies exclusively addressed individual perceptions of economic conditions $(n=18)$, in line with the conceptualizations of economic strain (Voydanoff, 1990) and economic pressure (Conger \& Elder, 1994) or both objective indicators and individual perceptions $(n=18)$. More than half of the studies $(n=21)$ used the set of questions proposed by Conger and Elder (1994) to assess economic hardship and economic pressure. With regard to this specific set of questions, different items were used across the multiple studies that were published by the aforementioned authors' team. One study adapted two economic strain-related questions from Voydanoff and Donnelly (1989). Another prevalent option to measure economic conditions was creating questions that were designed specifically for each study purpose $(n=9)$. Other studies used the Economic Strain Questionnaire (Pearlin, Menaghan, Lieberman, \& Mullan, 1981), either exclusively $(n=3)$ or together with the items from Conger and Elder $(n=4)$. Finally, the Family Economic Strain Scale was applied in 3 studies and the Income and Living Conditions instrument and the Consumer Sentiment Index were each used, once each in 2 studies. In designs 
Table 1

Overview of the Selected Studies

\begin{tabular}{|c|c|c|c|c|c|}
\hline \multirow[b]{2}{*}{ Context } & \multirow[b]{2}{*}{ Author(s), year } & \multicolumn{2}{|c|}{ Design } & \multirow[b]{2}{*}{ Other study variables } & \multirow[b]{2}{*}{ Outcome variable(s) } \\
\hline & & CS & LGT & & \\
\hline \multirow[t]{2}{*}{ USA, 1930s } & Liker and Elder (1983) & & $\mathrm{X}$ & Personal instability; Financial conflicts & Marital tension \\
\hline & $\begin{array}{l}\text { Elder, van Nguyen, and Caspi } \\
\text { (1985) }\end{array}$ & & $\mathrm{X}$ & $\begin{array}{l}\text { Parenting behavior; Children's } \\
\text { attractiveness }\end{array}$ & Child behavior \\
\hline \multirow[t]{13}{*}{ USA, 1980s } & Johnson and Booth (1990) & & $\mathrm{X}$ & Depression & $\begin{array}{l}\text { Marital happiness; Thinking } \\
\text { about divorce; Marital } \\
\text { communication }\end{array}$ \\
\hline & Conger et al. (1990) & $\mathrm{X}$ & & $\begin{array}{l}\text { Spousal hostility; Spousal warmth; } \\
\text { Marital quality }\end{array}$ & Marital instability \\
\hline & $\begin{array}{l}\text { Lorenz, Conger, Simon, } \\
\text { Whitbeck, and Elder (1991) }\end{array}$ & $\mathrm{X}$ & & Spousal hostility; Spousal warmth & Marital quality \\
\hline & $\begin{array}{l}\text { Elder, Conger, Foster, and } \\
\text { Ardelt (1992) }\end{array}$ & $\mathrm{X}$ & & $\begin{array}{l}\text { Depressed mood; Marital relations } \\
\text { (Hostility and warmth/support); } \\
\text { Parental hostility; Maternal support }\end{array}$ & $\begin{array}{l}\text { Children's negative mood and } \\
\text { antisocial behavior; Children's } \\
\text { aggressiveness }\end{array}$ \\
\hline & Conger et al. (1992) & $\mathrm{X}$ & & $\begin{array}{l}\text { Fathers' and mothers' depressed mood; } \\
\text { Marital conflict; Nurturing/Involved } \\
\text { parenting }\end{array}$ & $\begin{array}{l}\text { Adjustment of early adolescent } \\
\text { boys }\end{array}$ \\
\hline & Conger, Conger et al. (1993) & $\mathrm{X}$ & & $\begin{array}{l}\text { Fathers' and mothers' depressed mood; } \\
\text { Marital conflict; Nurturing/Involved } \\
\text { parenting }\end{array}$ & $\begin{array}{l}\text { Adjustment of early adolescent } \\
\text { girls }\end{array}$ \\
\hline & $\begin{array}{l}\text { Conger, Ge, Elder, Lorenz, and } \\
\text { Simons (1994) }\end{array}$ & & $\mathrm{X}$ & $\begin{array}{l}\text { Parent depressed mood; Marital conflict; } \\
\text { Parent-adolescent financial conflict; } \\
\text { Parent hostility toward adolescent }\end{array}$ & $\begin{array}{l}\text { Adolescents' internalizing and } \\
\text { externalizing symptoms }\end{array}$ \\
\hline & $\begin{array}{l}\text { Elder, Eccles, Ardelt, and Lord } \\
\text { (1995) }\end{array}$ & $\mathrm{X}$ & & $\begin{array}{l}\text { Parents' depressed affect; Marital } \\
\text { quality; Kin and friend support }\end{array}$ & Parental efficacy/effectiveness \\
\hline & $\begin{array}{l}\text { Lorenz, Conger, Montague, and } \\
\text { Wickrama (1993) }\end{array}$ & & $\mathrm{X}$ & $\begin{array}{l}\text { Spouse's emotional support; Sense of } \\
\text { control }\end{array}$ & Depression \\
\hline & $\begin{array}{l}\text { Ho, Lempers, and Clark- } \\
\text { Lempers (1995) }\end{array}$ & $\mathrm{X}$ & & $\begin{array}{l}\text { Parent-adolescent relationship; Marital } \\
\text { happiness }\end{array}$ & Adolescent self-esteem \\
\hline & $\begin{array}{l}\text { Williams, Conger, and Blozis } \\
\text { (2007) }\end{array}$ & & $\mathrm{X}$ & Parental hostility & $\begin{array}{l}\text { Interpersonal aggression during } \\
\text { adolescence }\end{array}$ \\
\hline & Mayhew and Lempers (1998) & $\mathrm{X}$ & & Supportive parenting; Parent self-esteem & Adolescent self-esteem \\
\hline & $\begin{array}{l}\text { Conger, Schofield, Conger, and } \\
\text { Neppl (2010) }\end{array}$ & & $\mathrm{X}$ & $\begin{array}{l}\text { Alpha personality; Parent distress; } \\
\text { Marital conflict; Parents' emotional } \\
\text { investments }\end{array}$ & $\begin{array}{l}\text { Young children development } \\
\text { outcomes }\end{array}$ \\
\hline Romania, 1990s & $\begin{array}{l}\text { Robila and Krishnakumar } \\
\text { (2005) }\end{array}$ & $\mathrm{X}$ & & $\begin{array}{l}\text { Perceived social support; Maternal } \\
\text { depression }\end{array}$ & Marital conflict \\
\hline Albania, 1990s & Kloep (1995) & & $\mathrm{X}$ & $\begin{array}{l}\text { Conflict between spouses; Parent } \\
\text { hostility; Parent-child relationships; } \\
\text { Marital happiness; Conflict between } \\
\text { parents; Social support }\end{array}$ & $\begin{array}{l}\text { Adolescent girls' depression and } \\
\text { antisocial behavior }\end{array}$ \\
\hline Germany, 1990s & Forkel and Silbereisen (2001) & $\mathrm{X}$ & & $\begin{array}{l}\text { Father's and mother's depressed mood; } \\
\text { Positive family climate }\end{array}$ & Adolescents' depressed mood \\
\hline Czech Republic, 1990s & $\begin{array}{l}\text { Hraba, Lorenz, and Pechacova } \\
\text { (2000) }\end{array}$ & & $\mathrm{X}$ & $\begin{array}{l}\text { Spousal irritability; Spousal behavioral } \\
\text { problems; Spousal depression; } \\
\text { Hostility toward the spouse }\end{array}$ & Marital instability \\
\hline \multirow[t]{5}{*}{ Finland, 1990s } & $\begin{array}{l}\text { Leinonen, Solantaus, and } \\
\text { Punamäki (2002) }\end{array}$ & $\mathrm{X}$ & & $\begin{array}{l}\text { Parents' mental health; Quality of } \\
\text { marital interaction }\end{array}$ & Quality of parenting \\
\hline & $\begin{array}{l}\text { Leinonen, Solantaus, and } \\
\text { Punamäki (2003) }\end{array}$ & $\mathrm{X}$ & & $\begin{array}{l}\text { Extra-familial social support; Family } \\
\text { structure }\end{array}$ & Quality of parenting \\
\hline & $\begin{array}{l}\text { Solantaus, Leinonen, and } \\
\text { Punamäki (2004) }\end{array}$ & $\mathrm{X}$ & $\mathrm{X}$ & $\begin{array}{l}\text { Parents' mental-health; Marital } \\
\text { interaction; Parenting quality; Boys' } \\
\text { and girls' prerecession mental health }\end{array}$ & $\begin{array}{l}\text { Adolescents boys' and girls' } \\
\text { internalizing and externalizing } \\
\text { symptoms }\end{array}$ \\
\hline & Kinnunen and Pulkkinen (1998) & $\mathrm{X}$ & & Depression; Marital hostility & Marital quality \\
\hline & Kinnunen and Feldt (2004) & $\mathrm{X}$ & & $\begin{array}{l}\text { Husband's and wife's psychological } \\
\text { distress }\end{array}$ & $\begin{array}{l}\text { Husband's and wife's marital } \\
\text { adjustment }\end{array}$ \\
\hline Bulgaria, 1990s & Botcheva and Feldman (2004) & $\mathrm{X}$ & & $\begin{array}{l}\text { Harsh parenting; Perceived support of } \\
\text { grandparents }\end{array}$ & Adolescents' depressive feelings \\
\hline Korea, 1990s & $\begin{array}{l}\text { Kwon, Rueter, Lee, Koh, and } \\
\text { Ok (2003) }\end{array}$ & $\mathrm{X}$ & & $\begin{array}{l}\text { Husbands' and wives' emotional } \\
\text { distress; Marital conflict }\end{array}$ & Marital satisfaction \\
\hline Turkey, 2001 & Aytaç and Rankin (2009) & $\mathrm{X}$ & & Emotional distress & Marital problems \\
\hline
\end{tabular}


Table 1 (continued)

\begin{tabular}{|c|c|c|c|c|c|}
\hline \multirow[b]{2}{*}{ Context } & \multirow[b]{2}{*}{ Author(s), year } & \multicolumn{2}{|c|}{ Design } & \multirow[b]{2}{*}{ Other study variables } & \multirow[b]{2}{*}{ Outcome variable(s) } \\
\hline & & $\mathrm{CS}$ & LGT & & \\
\hline \multirow[t]{3}{*}{ Argentina, 2000s } & Falconier (2010) & $\mathrm{X}$ & & $\begin{array}{l}\text { Female and male depression; Female } \\
\text { and male anxiety }\end{array}$ & $\begin{array}{l}\text { Female and male psychological } \\
\text { aggression toward the partner }\end{array}$ \\
\hline & Falconier and Epstein (2010) & $X$ & & $\begin{array}{l}\text { Female and male psychological } \\
\text { aggression toward the partner; } \\
\text { Female and male positive behaviors } \\
\text { toward the partner }\end{array}$ & $\begin{array}{l}\text { Female and male relationship } \\
\text { satisfaction }\end{array}$ \\
\hline & Falconier and Epstein (2011) & $\mathrm{X}$ & & $\begin{array}{l}\text { Female demand/ Male withdraw; Male } \\
\text { demand/ Female withdraw }\end{array}$ & $\begin{array}{l}\text { Female and male relationship } \\
\text { distress }\end{array}$ \\
\hline Singapore, 2008 & Han and Rothwell (2014) & $\mathrm{X}$ & & & $\begin{array}{l}\text { Family strains; Family } \\
\text { functioning (family } \\
\text { cohesiveness and family } \\
\text { support) }\end{array}$ \\
\hline Belgium, 2008 & $\begin{array}{l}\text { Ponnet, Wouters, Goedemé, and } \\
\text { Mortelmans (2014) }\end{array}$ & $\mathrm{X}$ & & $\begin{array}{l}\text { Fathers' and mothers' depressive } \\
\text { symptoms; Fathers' and mothers' } \\
\text { interparental conflict; Fathers' and } \\
\text { mothers' positive parenting }\end{array}$ & Adolescents' problem behavior \\
\hline \multirow[t]{7}{*}{ USA, 2007-2009 } & Helms et al. (2014) & $X$ & & $\begin{array}{l}\text { Husbands' and wives' depressive } \\
\text { symptoms; Husbands' and wives' } \\
\text { marital negativity }\end{array}$ & $\begin{array}{l}\text { Husbands' and wives' marital } \\
\text { satisfaction }\end{array}$ \\
\hline & $\begin{array}{l}\text { Brooks-Gunn, Schneider, and } \\
\text { Waldfogel (2013) }\end{array}$ & & $\mathrm{X}$ & & Maternal spanking \\
\hline & Diamond and Hicks (2012) & $\mathrm{X}$ & & $\begin{array}{l}\text { Partners' attributions for household } \\
\text { money problems }\end{array}$ & Relationship satisfaction \\
\hline & Stein et al. (2011) & $\mathrm{X}$ & & $\begin{array}{l}\text { Parent-child relationships; Concerns } \\
\text { about young adults' futures }\end{array}$ & $\begin{array}{l}\text { Depressed mood; Generalized } \\
\text { anxiety }\end{array}$ \\
\hline & $\begin{array}{l}\text { Murphy, Zemore, and Mulia } \\
\text { (2014) }\end{array}$ & $\mathrm{X}$ & & Perceived family support & $\begin{array}{l}\text { Negative drinking consequences; } \\
\text { Alcohol dependence } \\
\text { symptoms }\end{array}$ \\
\hline & Leininger and Kalil (2014) & $X$ & & $\begin{array}{l}\text { Caregiver psychosocial well-being: } \\
\text { Depressive symptoms, Parenting } \\
\text { stress, Family conflict }\end{array}$ & $\begin{array}{l}\text { Yong children/adolescents' } \\
\text { internalizing and externalizing } \\
\text { behavior problems }\end{array}$ \\
\hline & Puff and Renk (2014) & $\mathrm{X}$ & & Parenting stress & $\begin{array}{l}\text { Young children's internalizing, } \\
\text { externalizing, and total } \\
\text { problems }\end{array}$ \\
\hline
\end{tabular}

Note. $\mathrm{CS}=$ cross-sectional. $\mathrm{LGT}=$ longitudinal.

with more than one participant per family, the adults (couples/ parents) were most frequently the persons who reported on economic conditions. Out of the 29 studies, 15 studies created a single index by summing both partners' responses, 12 separately analyzed the individual results for each family member, and 2 studies did not report this information.

Family variables. With regard to family target variables, 16 studies primarily focused on couple-related variables and 10 on parenting-level variables; 9 studies included couple and parenting variables in their designs, and 4 addressed whole-family variables. Beyond observational ratings that assessed couple (e.g., marital interaction in terms of warmth/hostility; $n=7$ ) and parenting (e.g., parental hostility; $n=5$ ) domains, nearly half of the selected studies used questions that had been specifically designed for each study purpose to assess at least one variable (e.g., emotional distress, harsh parenting, marital quality). Among the four identified categories, a number of different assessment instruments were used, such as the Dyadic Adjustment Scale $(n=6)$, the Network of Relationship Inventory $(n=1)$, and the Family Environment Scale $(n=1)$.

\section{Families' Response to Macroeconomic Crises}

In line with the FSM, the assessment of the impact of changing economic conditions on family dynamics was identified as a main research trend in the literature $(n=36)$. In fact, the FSM constitutes the theoretical rationale of the majority of the studies in this review. Apart from studies prior to the model and those developed by the original team during the 1990s $(n=13), 19$ studies conducted in different countries drew upon this framework. Accordingly, the majority of the impact studies assessed the negative effects of changing economic conditions on couple and/or parenting variables. A secondary line of research examined the protective factors that could mitigate the previously mentioned impact, identifying the moderators of the relationships between economic conditions and family outcomes $(n=12)$. Both approaches have been also combined in the same study $(n=9)$.

Impact of macroeconomic crises on family dynamics. The results will next be presented according to the studies' focuses: the couple relationship, parenting, both couple and parenting dimensions, and the whole-family system. Following this, the results regarding the particular role of individual perceptions of economic conditions in the relation between objective indicators and family variables will be presented.

The couple relationship. Sixteen studies examined how changing economic conditions adversely influenced couples' outcomes directly or indirectly through individual and/or relational mediators. Five studies focused on individual mediators to assess individual psychological functioning. In addition to confirming 
these indirect links, 3 of these studies found direct effects between changing economic conditions and couples' outcomes, such as thoughts about divorce (Johnson \& Booth, 1990), marital conflict (Robila \& Krishnakumar, 2005), and marital adjustment (Kinnunen \& Feldt, 2004). The latter study also established crossover effects between psychological distress and marital adjustment for both men and women. Johnson and Booth (1990) reported a direct impact of economic distress on marital communication. The other 2 studies reported sex differences. In Turkey, direct links between economic strain and marital problems were found for both men and women, whereas indirect links via emotional distress were found only for women (Aytaç \& Rankin, 2009). In Argentina, economic strain was associated with psychologically aggressive behaviors, indirectly via anxiety for women and via depression for men (Falconier, 2010).

Relationship-level mediators were analyzed in 4 studies. Conger et al. (1990) found that husbands under economic strain tended to engage in patterns of marital interaction characterized by increased levels of hostility and decreased levels of warmth, which influenced wives' marital quality and instability. A second U.S. report replicated and extended the preceding study by encompassing participants' reports as well as observer ratings from videotapes of family interactions (Lorenz, Conger, Simon, Whitbeck, \& Elder, 1991). The authors concluded that the relationships between economic conditions and marital interactions were stronger and more consistent when observer ratings were employed compared with self-report assessments. In Argentina, husbands' economic strain was indirectly associated with wives' relationship satisfaction via partners' increased psychological aggression and wives' decreased positive behaviors (Falconier \& Epstein, 2010). In addition, under economic strain, wives appeared to behave in a more demanding manner, whereas husbands tended to withdraw more, generating a communication pattern that affected each partner's relationship distress (Falconier \& Epstein, 2011).

Finally, 5 studies focused on the link between changing economic conditions and outcomes related to couples' functioning, examining both individual- and relationship-level mediators. The results confirmed the mediating role of the following variables on the associations between economic stress and couples' outcomes: husbands' personality instability and increased conflicts over finances (Liker \& Elder, 1983); depressive symptoms and marital negativity (Helms et al., 2014); wives' emotional distress and marital satisfaction (Kwon, Rueter, Lee, Koh, \& Ok, 2003); husbands' and wives' irritability and hostility toward the partner and husbands' behavioral problems (Hraba et al., 2000). Particular sex differences were reported in a Finnish study (Kinnunen \& Pulkkinen, 1998) that found that the relationship between economic strain and marital quality was mediated by depression and marital hostility for men, whereas depression mediated the relationship between economic strain and marital hostility for women. Crossover effects were verified by Helms et al. (2014) among Mexicanorigin couples in the U.S.: Husbands' depressive symptoms were associated with wives' marital negativity, and husbands' marital negativity was linked with wives' lower marital satisfaction. Finally, a direct effect between economic pressure and marital conflict was also found in the Korean study (Kwon et al., 2003).

Parenting. For families with young children, parenting stress was found to mediate the links between financial cutbacks and children's internalizing problems and between negative economic events and children's externalizing problems (Puff \& Renk, 2014). Additionally, 1 study (also from the U.S.) drew attention to an increased risk of high-frequency maternal spanking associated with decreased levels of consumer confidence during the Great Recession (Brooks-Gunn et al., 2013).

With regard to families with adolescent children, 5 studies verified a negative indirect association between changing economic conditions and adolescents' adjustment outcomes through changes in parenting (Botcheva \& Feldman, 2004; Elder, van Nguyen, \& Caspi, 1985; Mayhew \& Lempers, 1998; Ponnet et al., 2014; Williams, Conger, \& Blozis, 2007). These findings varied according to sex; Elder et al. (1985) showed that fathers' rejecting behavior adversely influenced girls' psychosocial well-being. Mayhew and Lempers (1998) identified adolescents' perceptions of supportive parenting as a mediator variable in the relationship between financial strain and adolescents' self-esteem in the context of mother/son, father/daughter, and father/son dyads. In Belgium, the adverse impact of financial stress on parenting was found to be greater for fathers than mothers (Ponnet et al., 2014). Additionally, two studies (Elder et al., 1995; Leinonen, Solantaus, \& Punamäki, 2003) demonstrated the adverse effects of changing economic conditions on parenting behavior variables. The study by Elder et al. (1995) found that parents' depressed affect mediated the link between economic pressure and parental ineffectiveness in both Black and White families, with a direct link between these variables being valid for Black families.

Regarding families with young adults, the results from Stein et al. (2011) suggested different impact trends among participants. Parental concerns about their children's sacrificing to assist them in the future and children's career choices accounted for the variations in their reports of anxiety and depressed mood, above and beyond economic pressure and parent-child relationship reports; for young adults, it was their reports of economic pressure that were positively related to their anxiety and depressed mood.

Couple and parenting domains. Research addressing these domains was able to demonstrate that, under economic pressure, problems in the marital relationship were related to disrupted parenting skills, which in turn was associated with children's poorer adjustment (Conger et al., 1992, 1994, 2010; Conger, Conger et al., 1993; Elder, Conger, Foster, \& Ardelt, 1992; Solantaus et al., 2004). Once again, variations according to sex were reported. Contrary to what was found for adolescent boys (Conger et al., 1992), for girls, parental depression was associated directly with positive development outcomes (Conger, Conger et al., 1993). In the Finnish study (Solantaus et al., 2004), children's prerecession mental health problems were found to predict the quality of parenting, which in turn reflected on children's internalizing and externalizing symptoms during the recession. In a similar way, a study from Albania found that the problem behaviors exhibited by daughters under economic distress seemed to induce a more hostile and less nurturing parenting style (Kloep, 1995).

In contrast to the previous data, 1 study found neither direct nor indirect associations between the evaluated dimensions of marital functioning and adolescents' adjustment in times of economic hardship (Ho, Lempers, \& Clark-Lempers, 1995). Finally, Leinonen, Solantaus, and Punamäki (2002) established that under economic pressure, fathers responded by showing anxiety and social dysfunction, whereas mothers responded in terms of anxiety 
and depression, affecting the way both interacted with other family members; fathers became more hostile toward their wives, wives became less supportive of their husbands, and both, especially fathers, became more punitive, more uninvolved, and less authoritative with their children.

Whole-family domain. The present review identified 2 studies that included parenting and family level variables and 1 study that focused exclusively on the family system as a whole. With regard to the former, among a West German subsample, the relationship between economic pressure and adolescents' outcomes was found to be mediated by fathers' and mothers' depressed moods, the latter being negatively associated with family climate (Forkel \& Silbereisen, 2001). In contrast, among the East German subsample, separate from the path from objective indicators of economic conditions to economic pressure, only the path from mothers' depressed mood to family climate was significant. In the U.S., economic strain was linked to young White children's and adolescents' internalizing behavior problems, but unexpectedly, this relationship was not driven by parents' depressive symptoms, parenting stress, or family conflict (Leininger \& Kalil, 2014). Finally, 1 study from Singapore (Han \& Rothwell, 2014) showed that decreased savings related to economic crisis were associated with impaired family functioning.

Links between objective indicators, individual perceptions of economic conditions, and family variables. Fifteen studies attested the mediating role of individual perceptions in the associations between objective indicators of economic conditions and family outcomes proposed by the FSM (e.g., Leinonen et al., 2002). Additionally, three European studies identified direct links between objective indicators of economic conditions and family variables, namely (a) women's unstable career paths and increased marital hostility, and decreased marital quality (Kinnunen \& Pulkkinen, 1998); (b) greater length of unemployment among men and women's decreased marital adjustment (Kinnunen \& Feldt, 2004); and (c) lower household income and higher depression among mothers (Ponnet et al., 2014).

Protective factors against the impact of macroeconomic crises on family dynamics. These findings will be presented according to the four types of protective factors identified: individual, couple, parental, and family/extrafamiliar protective factors.

Individual protective factors. Two studies (Conger et al., 2010; Liker \& Elder, 1983) provided insight into the role of earlier personality characteristics in adapting to economic crises. Specifically, Liker and Elder (1983) reported that husbands who exhibited a calm and even-tempered disposition prior to the 1930s recession were able to remain less affected by economic loss, including in terms of marital quality. Conger et al. (2010) found that the positive personality attributes of adolescents who were assessed after the farm crisis predicted less economic pressure during their adulthood; in addition, fewer negative family processes related to economic pressure were expected to affect their younger children's development. A third study (Elder et al., 1985) suggested evidence of the protective role of children's physical attractiveness in that economically stressed fathers were revealed to be less rejecting of more attractive daughters. Diamond and Hicks (2012) demonstrated that couples' relationship satisfaction was less affected if partners, especially the women, blamed the national economic crisis for their household money problems rather than exclusively blaming the partner.
Couple-related protective factors. Two studies demonstrated the protective role of marital relationship quality. Elder et al. (1995) found that African American couples who assessed their marriage as strong were less affected by economic crises. Liker and Elder (1983) found that marital quality was more likely to be reduced by economic pressure when marital relationships were already weak before the 1930 s recession. In addition, 2 studies examined the more specific protective role of marital interaction. First, spousal support was found to buffer the impact of economic pressure on both spouses' levels of depression, directly for wives and indirectly through personal sense of control for both husbands and wives (Lorenz, Conger, Montague, \& Wickrama, 1993). In Finland, it was shown that when parents perceived their marital interaction as warm and supportive, the links between economic hardship and punitive mothering and fathering (self-reported) and nonauthoritative fathering (child-reported) were weaker (Leinonen et al., 2002).

Parenting-related protective factors. Within the parenting domain, Elder et al. (1992) reported that exposure to paternal hostility involved no meaningful risk for adolescents when mothers were highly supportive.

Family and extrafamiliar protective factors. Three studies examined the role of social support. In Albania, children's depressive behavior was found to be reduced by social support received from persons other than the parents (Kloep, 1995). In Finland, extrafamilial social support was revealed to be beneficial to parenting quality among mothers and single fathers (Leinonen et al., 2003). In contrast, among US single-parent Black families, kin and friend support did not moderate the impact of economic pressure on emotional distress (Elder et al., 1995). Additionally, perceived family support was found to reduce the adverse impacts on alcohol problems of housing instability in times of economic crisis (Murphy, Zemore, \& Mulia, 2014). Finally, in Bulgaria, grandparent support was found to buffer the relationship between economic pressure and harsh mothering as well as the relationship between harsh parenting and adolescent depression (Botcheva \& Feldman, 2004).

\section{Discussion}

Three main conclusions were identified in the present review. First, family dynamics undergo negative changes when family members report adverse economic conditions in critical macroeconomic times. Second, protective factors across different systemic levels appeared to mitigate, to some extent, the disruption of macroeconomic crises on family dynamics. Third, nearly half of the studies in this review $(n=19)$ suggested sex-related differences in the response to macroeconomic crisis demands.

Research that supports the first conclusion is consistent with the pathways predicted by the FSM (Conger \& Conger, 2002). Individuals who are stressed about their financial situations tended to display impaired psychological functioning, which influenced the way they behaved as partners and parents. Couples seemed to engage in poorer styles of communication that were marked by hostility and decreased support, which affected their relationship satisfaction. Parents appeared to engage in more hostile, rejecting, and punitive parenting styles. Through these negative changes in parents' behaviors, economic pressure negatively affected children's health and well-being outcomes. 
This review shows that the FSM, a framework associated with the early developments of the research on the interfaces between macroeconomic crises and family dynamics, continues to be widely endorsed by researchers around the world to understand this phenomenon. Importantly, these results from different countries suggest that there might be universal features in how families experience macroeconomic crises. Nevertheless, some variations appeared among this solid body of research, such as the following: (a) direct effects between perceptions of economic distress and couples' outcomes in a subset of studies from different countries (e.g., Johnson \& Booth, 1990; Kinnunen \& Feldt, 2004; Robila \& Krishnakumar, 2005), (b) children appeared to respond directly to parents' perceptions of economic strain in the study by Leininger and Kalil (2014), and (c) direct links between objective indicators of economic conditions and individual and familial psychological responses (e.g., Kinnunen \& Pulkkinen, 1998). These direct links that were found in addition to or instead of the more traditional mediating paths that have been previously examined (e.g., emotional distress, economic pressure) might shed light on some specificities regarding families' experiences of economic downturns. Put simply, unexpected and perhaps unprecedented macroeconomic crises might quickly undermine families' finances. Unprepared to deal with such sudden and serious demands, families might experience more acute impacts of economic stressors related to macroeconomic shocks, which might be expressed in the direct effects that were found (Aytaç \& Rankin, 2009; Kwon et al., 2003). These preliminary findings could suggest that families' responses to such events might vary more because of to the characteristics of the macroeconomic crisis (e.g., severity, unexpectedness) than to the particular geographic location where the crisis occurs. This hypothesis should be examined in future research.

In regard to the second main conclusion of this review, protective factors were found across different systemic levels: individual, couple, and familial/extrafamilial. The inconsistent results regarding the lack of significance of social support as a protective factor of economic pressure on emotional distress in the study of Elder et al. (1995) might reflect measurement issues. These authors assessed social support through the number of relatives who were available to assist parents, whereas other studies (Kloep, 1995; Leinonen et al., 2003) encompassed a more comprehensive assessment of the quality of social support. Along with this hypothesis, the specific sample used in the referred study (African American single parents) might also explain the reported inconsistency.

Within the research on factors that could protect families from the negative impacts of changing economic conditions, an innovative hypothesis arises from the findings of 3 particular studies (Diamond \& Hicks, 2012; Forkel \& Silbereisen, 2001; Ho et al., 1995). Is it possible that families who attribute their economic problems to the macroeconomic crisis scenario experience the consequences of such stressors in a less severe way? Diamond and Hicks (2012) raised this possibility considering that macroeconomic crises function as a scapegoat for a family's daily economic challenges. The nonsignificant association between marital problems and children's outcomes in the study by Ho et al. (1995) might be explained by this rationale; rather than blaming themselves for their parents' marital problems, adolescents might associate these conflicts with the family's increased macroeconomic demands (Ho et al., 1995). Additional support for this hypothesis is gained by the contrasting pattern of results from East and West Germany (Forkel \& Silbereisen, 2001): Among the East German participants, economic hardship was perceived as a mass phenomenon or collective adversity, which might explain why these families did not show adverse impacts from economic distress.

Regarding the third main conclusion, it appears that the identified sex differences mirrored specific gender role ideology. For instance, a subset of studies showed that women seemed to play a more predominant role in channeling economic and emotional distress to other family domains (e.g., Aytaç \& Rankin, 2009; Forkel \& Silbereisen, 2001; Kwon et al., 2003), but men appeared to present greater susceptibility to economic distress with regard to their parenting role (e.g., Elder et al., 1985; Ponnet et al., 2014); furthermore, girls seemed to be more vulnerable to their fathers' stress than boys (Conger, Conger et al., 1993; Elder et al., 1985). In addition, men appeared to react to economic pressure in a more behavioral and functional way (e.g., Conger et al., 1990; Hraba et al., 2000; Kinnunen \& Pulkkinen, 1998), whereas women tended to show more emotional responses (e.g., Leinonen et al., 2002). These findings are consistent with previous literature on sex differences in two-parent families in which the husbands are the primary breadwinners (Conger, Lorenz, Elder, Simons, \& Ge, 1993). In general, men continue to be expected to provide for their family, whereas women are expected to nurture the family relationships (Aytaç \& Rankin, 2009; Conger et al., 1992; Forkel \& Silbereisen, 2001). Thus, increasing family economic pressure might affect men and women differently because it interferes with successfully fulfilling differentiated roles. Finally, unidirectional crossover effects suggested that women were more likely to be affected by their husbands' stress in a North American study with Mexican-origin couples (Helms et al., 2014), which might translate specific gendered cultural norms. A Finnish study (Kinnunen \& Feldt, 2004) revealed bidirectional effects between individual and marital outcomes for both men and women, which can be explained through the relatively equal roles between men and women in that country. In sum, understanding sex differences regarding the experience of macroeconomic crises requires a macro and sociocultural perspective with emphasis on the diversity of gender role ideologies and important social transformations, such as the continuously changing role of women in the workforce.

\section{Research Critique and Future Directions}

A first critique of the current literature involves the conceptualization and assessment of economic condition variables. Frequently, researchers have been using the terms "economic pressure" and "economic strain" interchangeably (e.g., Aytaç \& Rankin, 2009; Conger et al., 1990). Importantly, economic pressure expands upon the concept of economic strain, measuring a wide range of specific economic experiences (e.g., inability to pay bills) rather than global economic evaluations (Conger, Rueter, \& Elder, 1999). The occurrence of acute events stemming from the macroeconomic crisis (e.g., job loss) is usually integrated into a general economic hardship indicator along with other variables (e.g., income level/change). Given the probable major impact of these types of events on family life, researchers should examine these variables separately in further studies. To assess economic and family variables, studies have used indexes that were generated for each study purpose. Although this option was valid in the 
initial context of exploring this research topic, future research should use validated assessment instruments with known psychometric properties. Moreover, further studies examining which selfreport measures of economic conditions are more suitable for research on macroeconomic crisis and family dynamics would be valuable. Additionally, regarding the assessment of family dynamics, there are advantages to using mixed-methods approaches, as described in one of the selected studies (Lorenz et al., 1991). Accordingly, the observational measures that were used in 10 studies in this review contribute to reduce the self-report bias and constitute a strength in the literature.

A major research skew identified by this review was the predominance of study samples involving two-parent families with adolescent children; future studies should include families in different stages of their life cycles. This recommendation gains additional relevance considering the different patterns of results found in the selected study with families with young adult children (Stein et al., 2011) compared with the results from the studies that investigated families with adolescents. In addition, future research can also benefit from including single, step, and extended families and other family members beyond parents and children as participants.

As most of the reviewed studies strived to understand the impact of economic difficulties on families' dynamics, the current literature on the interfaces between macroeconomic crisis and family life does not provide a comprehensive view of how families manage to achieve postcrisis adaptation, moving on from the demand-capability imbalance phase, according to the FAAR (McCubbin \& Patterson, 1983). Moreover, couple and parenting dimensions were extensively examined, but research at the whole family level was scarce. Research has yet to investigate these variables (e.g., family functioning, cohesion, rituals), which might operate as family positive resources in facing macroeconomic demands. In fact, this line of research is of major relevance, and future investigations might draw upon general stress and resilience theories such as the FAAR model or the relational resilience framework (Walsh, 2006), which suggest key family processes (e.g., flexibility, spirituality) as being associated with positive adaptation in risk contexts. In addition, empirical studies attesting the role of such family variables in the adaptation to negative macroeconomic events could contribute to an extension of the FSM by specifying some of the psychological and social resources that might reduce the economic stress process as initially posited by the authors' model (Conger \& Conger, 2002).

Additionally, in light of the hypothesis raised in this review of the buffering role of external causal attributions (e.g., reflex of macroeconomic trends) to family problems for family and individual adaptation, future studies can benefit from investigating the meanings ascribed to macroeconomic crises. Support for this line of research stems directly from the FAAR model, which postulates that the meanings families ascribe to the stressor event are a critical factor in restoring balanced functioning (McCubbin \& Patterson, 1983). In this regard, both qualitative and longitudinal research designs would be of particular relevance.

Furthermore, it is legitimate to expect that the interaction between the influences of the crisis and the preexisting socioeconomic conditions will be of special relevance to understand how families navigate times of macroeconomic crisis. Nonetheless, the reviewed studies did not address this issue, which might be par- tially explained by the prevalence of middle-class families in their samples. An exception was made by Liker and Elder (1983), who advanced that dealing with sudden declines in financial resources due to a macroeconomic crisis appears to be more stressful than experiencing a more chronic and persistent economic hardship, as economic changes accentuate the discrepancy between the family's customary needs and the resources available to achieve those needs. Further studies are warranted to obtain more solid conclusions concerning this topic.

Finally, considering the accumulated knowledge on the detrimental impact of economic difficulties on families' lives, strategies to assist families during macroeconomic crises should be addressed in future investigations. A recent intervention study (Falconier, 2015) offered encouraging results. After participation in an interdisciplinary couples' program, North American couples reported improvements in their financial management skills, common dyadic coping, and relationship satisfaction. Furthermore, developing and validating intervention approaches that aim to support families during economic challenges might contribute to the cross-fertilization of research and clinical practice.

\section{Limitations, Strengths, and Conclusion}

The current review presents limitations. First, 9 out of the 39 studies reviewed were conducted by Conger's team in the 1980, thus, to a certain extent, concentrating the conclusions to that specific macroeconomic crisis period. Moreover, this review was not able to accurately differentiate which national studies conducted by the same authors drew upon the same samples. This might be an issue not only concerning Conger's studies, but also the studies conducted in Finland (e.g., Leinonen et al., 2002; Solantaus et al., 2004) and Argentina (e.g., Falconier \& Epstein, 2010, 2011). Therefore, caution should be exercised in interpreting this review's conclusions. Second, the heterogeneity of designs and assessment instruments that were adopted in the reviewed studies precluded more fine-tuned findings. Third, although several aspects of the reviewed studies were scrutinized, a formal quality assessment was not performed. This option was chosen as the vast majority of the studies did not report on potentially relevant criteria for assessing the risk of bias, such as the representativeness of samples or effect sizes' values. This constitutes an important limitation in this work, as the methodological aspects that might have a bearing on the conclusions of the review were not fully evaluated.

Finally, the criterion regarding English language in the research strategy and in the selection of databases that were used for the literature searches might have introduced publication bias. Nonetheless, this review was able to identify studies that were conducted in 12 different countries across three continents, providing insight into worldwide similarities in families' experiences with macroeconomic crises as well as into the importance of attending to cultural norms for the purpose of understanding sex differences when facing macroeconomic demands. The present review illustrated that the literature on families' responses to macroeconomic crises has primarily focused on the adverse impacts of economic distress on different dimensions of family functioning and that research on family capabilities that might lead to positive adaptations is scarce. Therefore, a shift from the traditional focus on 
"what goes wrong" to a more family-strength-focused approach in future research is particularly important. This review was, to the best of our knowledge, the first attempt to systematically address the literature on the interfaces between macroeconomic crises and family dynamics. Ultimately, implications from the present findings may guide multisystemic interventions that aim to assist families that face macroeconomic demands given that such stressors can severely disrupt daily life and impair individual and family adaptation.

\section{References}

References marked with an asterisk indicate studies included in the systematic review.

*Aytaç, I. A., \& Rankin, B. H. (2009). Economic crisis and marital problems in Turkey: Testing the family stress model. Journal of Marriage and Family, 71, 756-767. http://dx.doi.org/10.1111/j.1741-3737 .2009.00631.x

*Botcheva, L. B., \& Feldman, S. (2004). Grandparents as family stabilizers during economic hardship in Bulgaria. International Journal of Psychology, 39, 157-168. http://dx.doi.org/10.1080/00207590344000321

Bronfenbrenner, U. (1979). The ecology of human development. Cambridge, MA: Harvard University Press.

*Brooks-Gunn, J., Schneider, W., \& Waldfogel, J. (2013). The Great Recession and the risk for child maltreatment. Child Abuse \& Neglect, 37, 721-729. http://dx.doi.org/10.1016/j.chiabu.2013.08.004

Conger, R. D., \& Conger, K. J. (2002). Resilience in Midwestern families: Selected findings from the first decade of a prospective, longitudinal study. Journal of Marriage and Family, 64, 361-373. http://dx.doi.org/ 10.1111/j.1741-3737.2002.00361.x

"Conger, R. D., Conger, K. J., Elder, G. H., Jr., Lorenz, F. O., Simons, R. L., \& Whitbeck, L. B. (1992). A family process model of economic hardship and adjustment of early adolescent boys. Child Development, 63, 526-541. http://dx.doi.org/10.2307/1131344

"Conger, R. D., Conger, K. J., Elder, G. H., Lorenz, F. O., Simons, R. L., \& Whitbeck, L. B. (1993). Family economic stress and adjustment of early adolescent girls. Developmental Psychology, 29, 206-219. http:// dx.doi.org/10.1037/0012-1649.29.2.206

Conger, R. D., \& Elder, G. H. (1994). Families in troubled times: Adapting to change in rural America. Hawthorne, NY: Aldine de Gruyter.

*Conger, R. D., Elder, G. H., Lorenz, F. O., Conger, K. J., Simons, R. L., Whitbeck, L. B., .. Melby, J. N. (1990). Linking economic hardship to marital quality and instability. Journal of Marriage and the Family, 52, 643-656. http://dx.doi.org/10.2307/352931

"Conger, R. D., Ge, X., Elder, G. H., Jr., Lorenz, F. O., \& Simons, R. L. (1994). Economic stress, coercive family process, and developmental problems of adolescents. Child Development, 65, 541-561. http://dx.doi .org/10.2307/1131401

Conger, R. D., Lorenz, F. O., Elder, G. H., Jr., Simons, R. L., \& Ge, X. (1993). Husband and wife differences in response to undesirable life events. Journal of Health and Social Behavior, 34, 71-88. http://dx.doi .org/10.2307/2137305

Conger, R. D., Rueter, M. A., \& Elder, G. H., Jr. (1999). Couple resilience to economic pressure. Journal of Personality and Social Psychology, 76, 54-71. http://dx.doi.org/10.1037/0022-3514.76.1.54

"Conger, R. D., Schofield, T. K., Conger, K. J., \& Neppl, T. K. (2010). Economic pressure, parent personality and child development: An interactionist analysis. Historische Sozialforschung [Historical Social Research], 35, 169-194.

De Vogli, R. (2014). The financial crisis, health and health inequities in Europe: The need for regulations, redistribution and social protection. International Journal for Equity in Health, 13, 58. http://dx.doi.org/10 $.1186 / \mathrm{s} 12939-014-0058-6$
"Diamond, L. M., \& Hicks, A. M. (2012). "It's the economy, honey!" Couples' blame attributions during the 2007-2009 economic crisis. Personal Relationships, 19, 586-600. http://dx.doi.org/10.1111/j.14756811.2011.01380.x

*Elder, G. H., Conger, R. D., Foster, E. M., \& Ardelt, M. (1992). Families under economic pressure. Journal of Family Issues, 13, 5-37. http://dx .doi.org/10.1177/019251392013001002

*Elder, G. H., Eccles, J. S., Ardelt, M., \& Lord, S. (1995). Inner-city parents under economic pressure: Perspectives on the strategies of parenting. Journal of Marriage and the Family, 57, 771-784. http://dx .doi.org/10.2307/353931

*Elder, G. H., Jr., van Nguyen, T., \& Caspi, A. (1985). Linking family hardship to children's lives. Child Development, 56, 361-375. http://dx .doi.org/10.2307/1129726

"Falconier, M. K. (2010). Female anxiety and male depression: Links between economic strain and psychological aggression in Argentinean couples. Family Relations, 59, 424-438. http://dx.doi.org/10.1111/j $.1741-3729.2010 .00613 . x$

Falconier, M. K. (2015). Together-A couples' program to improve communication, coping, and financial management skills: Development and initial pilot-testing. Journal of Marital and Family Therapy, 41, 236250. http://dx.doi.org/10.1111/jmft. 12052

*Falconier, M. K., \& Epstein, N. B. (2010). Relationship satisfaction in Argentinean couples under economic strain: Gender differences in a dyadic stress model. Journal of Social and Personal Relationships, 27, 781-799. http://dx.doi.org/10.1177/0265407510373260

*Falconier, M. K., \& Epstein, N. B. (2011). Female-demand/malewithdraw communication in Argentinian couples: A mediating factor between economic strain and relationship distress. Personal Relationships, 18, 586-603. http://dx.doi.org/10.1111/j.1475-6811.2010 .01326.x

"Forkel, I., \& Silbereisen, R. K. (2001). Family economic hardship and depressed mood among young adolescents from former East and West Germany. American Behavioral Scientist, 44, 1955-1971. http://dx.doi .org/10.1177/00027640121958131

*Han, C.-K., \& Rothwell, D. W. (2014). Savings and family functioning since the 2008 recession: An exploratory study in Singapore. International Social Work, 57, 630-644. http://dx.doi.org/10.1177/ 0020872812444482

*Helms, H. M., Supple, A. J., Su, J., Rodriguez, Y., Cavanaugh, A. M., \& Hengstebeck, N. D. (2014). Economic pressure, cultural adaptation stress, and marital quality among Mexican-origin couples. Journal of Family Psychology, 28, 77-87. http://dx.doi.org/10.1037/a0035738

*Ho, C. S., Lempers, J. D., \& Clark-Lempers, D. S. (1995). Effects of economic hardship on adolescent self-esteem: A family mediation model. Adolescence, 30, 117-131.

*Hraba, J., Lorenz, F. O., \& Pechacova, Z. (2000). Family stress during the Czech transformation. Journal of Marriage and the Family, 62, 520 531. http://dx.doi.org/10.1111/j.1741-3737.2000.00520.x

*Johnson, D. R., \& Booth, A. (1990). Rural economic decline and marital quality: A panel study of farm marriages. Family Relations, 39, 159165. http://dx.doi.org/10.2307/585718

*Kinnunen, U., \& Feldt, T. (2004). Economic stress and marital adjustment among couples: Analyses at the dyadic level. European Journal of Social Psychology, 34, 519-532. http://dx.doi.org/10.1002/ejsp.213

*Kinnunen, U., \& Pulkkinen, L. (1998). Linking economic stress to marital quality among Finnish marital couples. Journal of Family Issues, 19, 705-724. http://dx.doi.org/10.1177/019251398019006003

*Kloep, M. (1995). Concurrent and predictive correlates of girls' depression and antisocial behaviour under conditions of economic crisis and value changes: The case of Albania. Journal of Adolescence, 18, 445458. http://dx. http://dx.doi.org/10.1006/jado.1995.1032

*Kwon, H., Rueter, M. A., Lee, M., Koh, S., \& Ok, S. W. (2003). Marital relationships following the Korean economic crisis: Applying the family 
stress model. Journal of Marriage and Family, 65, 316-325. http://dx .doi.org/10.1111/j.1741-3737.2003.00316.x

*Leininger, L., \& Kalil, A. (2014). Economic strain and children's behavior in the aftermath of the great recession. Journal of Marriage and Family, 76, 998-1010. http://dx.doi.org/10.1111/jomf.12140

*Leinonen, J. A., Solantaus, T. S., \& Punamäki, R. (2002). The specific mediating paths between economic hardship and the quality of parenting. International Journal of Behavioral Development, 26, 423-435. http://dx.doi.org/10.1080/01650250143000364

"Leinonen, J. A., Solantaus, T. S., \& Punamäki, R.-L. (2003). Social support and the quality of parenting under economic pressure and workload in Finland: The role of family structure and parental gender. Journal of Family Psychology, 17, 409-418. http://dx.doi.org/10.1037/ 0893-3200.17.3.409

"Liker, J. K., \& Elder, G. H., Jr. (1983). Economic hardship and marital relations in the 1930s. American Sociological Review, 48, 343-359. http://dx.doi.org/10.2307/2095227

*Lorenz, F. O., Conger, R. D., Montague, R. B., \& Wickrama, K. A. S. (1993). Economic conditions, spouse support, and psychological distress of rural husbands and wives. Rural Sociology, 58, 247-268. http://dx .doi.org/10.1111/j.1549-0831.1993.tb00493.x

"Lorenz, F. O., Conger, R. D., Simon, R. L., Whitbeck, L. B., \& Elder, G. H. (1991). Economic pressure and marital quality: An illustration of the method variance problem in the causal modeling of family processes. Journal of Marriage and the Family, 53, 375-388. http://dx.doi.org/10 $.2307 / 352906$

*Mayhew, K. P., \& Lempers, J. D. (1998). The relation among financial strain, parenting, parent self-esteem, and adolescent self-esteem. The Journal of Early Adolescence, 18, 145-172. http://dx.doi.org/10.1177/ 0272431698018002002

McCubbin, H. I., \& Patterson, J. M. (1983). The family stress process: The double ABCX model of adjustment and adaptation. In H. I. McCubbin, M. M. Sussman, \& J. M. Patterson (Eds.), Social stress and the family: Advances and developments in family stress theory and research (pp. 7-37). New York, NY: Guilford Press. http://dx.doi.org/10.1300/ J002v06n01_02

McHugh, M. L. (2012). Interrater reliability: The kappa statistic. Biochemia Medica, 22, 276-282. http://dx.doi.org/10.11613/BM.2012.031

"Murphy, R. D., Zemore, S. E., \& Mulia, N. (2014). Housing instability and alcohol problems during the 2007-2009 US recession: The moder- ating role of perceived family support. Journal of Urban Health, 91, 17-32. http://dx.doi.org/10.1007/s11524-013-9813-z

Pearlin, L. I., Menaghan, E. G., Lieberman, M. A., \& Mullan, J. T. (1981). The stress process. Journal of Health and Social Behavior, 22, 337-356. http://dx.doi.org/10.2307/2136676

*Ponnet, K., Wouters, E., Goedemé, T., \& Mortelmans, D. (2014). Family financial stress, parenting and problem behavior in adolescents: An actor-partner interdependence approach. Journal of Family Issues, 43, $1752-1769$.

*Puff, J., \& Renk, K. (2014). Relationships among parents' economic stress, parenting, and young children's behavior problems. Child Psychiatry and Human Development, 45, 712-727. http://dx.doi.org/10 .1007/s10578-014-0440-z

*Robila, M., \& Krishnakumar, A. (2005). Effects of economic pressure on marital conflict in Romania. Journal of Family Psychology, 19, $246-$ 251. http://dx.doi.org/10.1037/0893-3200.19.2.246

*Solantaus, T., Leinonen, J., \& Punamäki, R.-L. (2004). Children's mental health in times of economic recession: Replication and extension of the family economic stress model in Finland. Developmental Psychology, 40, 412-429. http://dx.doi.org/10.1037/0012-1649.40.3.412

*Stein, C. H., Abraham, K. M., Bonar, E. E., Leith, J. E., Kraus, S. W., Hamill, A. C., . . Fogo, W. R. (2011). Family ties in tough times: How young adults and their parents view the U.S. economic crisis. Journal of Family Psychology, 25, 449-454. http://dx.doi.org/10.1037/a0023697

Voydanoff, P. (1990). Economic distress and family relations: A review of the eighties. Journal of Marriage and the Family, 52, 1099-1115. http://dx.doi.org/10.2307/353321

Voydanoff, P., \& Donnelly, B. W. (1989). Economic distress and mental health: The role of family coping resources and behaviors. Lifestyles Family and Economic Issues, 10, 139-162. http://dx.doi.org/10.1007/ BF00988534

Walsh, F. (2006). Strengthening family resilience (2nd ed.). New York, NY: The New York: Guilford Press.

*Williams, S. T., Conger, K. J., \& Blozis, S. A. (2007). The development of interpersonal aggression during adolescence: The importance of parents, siblings, and family economics. Child Development, 78, 15261542. http://dx.doi.org/10.1111/j.1467-8624.2007.01081.x

Received January 14, 2016

Revision received June 20, 2016

Accepted June 20, 2016 